Yüzüncü Yil Üniversitesi
Tarim Bilimleri Dergisi

Araştırma Makalesi (Research Article)

Effects of Different Sowing Times and Phosphorus Application on Yield and Quality of Camelina (Camelina sativa L. Crantz)

\author{
Ruveyde TUNCTURK*, Haluk KULAZ, Murat TUNCTURK \\ Department of Field Crops, Faculty of Agriculture, Van Yuzuncu Yil University, 65080 Van, Turkey \\ *Corresponding Author e-mail: ruveydetuncturk@yyu.edu.tr
}

\section{Makale Bilgileri}

Geliş: 11.02 .2019

Kabul: 21.05.2019

Online Yayınlanma 28.06.2019

DOI: 10.29133/yyutbd.525311

\section{Keywords}

Camelina sativa L., Phosphorus application, Sowing times,

Yield

\begin{abstract}
This study was carried out for determination effects of sowing time and phosphorus applications on several yield and quality components of Camelina sativa (L.) Crantz during 2014-2015 years in Van/Turkey ecological conditions. The factorial experiment was designed based on split plot with two factors including (A) sowing times (7-10 April, 22-25 April and 7-10 May) and (B) phosphorus fertilization $\left(0,40\right.$ and $\left.80 \mathrm{~kg} \mathrm{ha}^{-1} \mathrm{P}_{2} \mathrm{O}_{5}\right)$ in three replicates. Several yield and quality parameters such as plant height, first capsule height, number of branches, number of capsules, number of seeds in each capsule, thousand seed weight, seed yield, oil content as well as yield were measured. Results showed that sowing times had significant effects on all parameters except for seed numbers per capsule and oil contents $(\mathrm{P}<0.05)$. The most values for first capsule height $(28.86 \mathrm{~cm})$ and thousand seeds weight $(0.94 \mathrm{gr})$ observed at 7-10 April sowing time, while the highest amounts of number of branches (12.48 branch plant ${ }^{-1}$ ), number of capsule (130.33 capsule plant ${ }^{-1}$ ), seed yield (1128.6 kg ha-1) and oil yield (328.0 $\mathrm{kg} \mathrm{ha}^{-1}$ ) were obtained at 22-25 April and 7-10 May. On the other hand, the effects of phosphorus application was statistically significant $(\mathrm{P}<0.05)$ on first capsule height, number of branches, number of capsules and thousand seeds weight. The most value for first capsule height $(28.56 \mathrm{~cm})$ was determined using $40 \mathrm{~kg} \mathrm{ha}^{-1} \mathrm{P}_{2} \mathrm{O}_{5}$ application, while the highest number of branches (12.41 branch plant $\left.{ }^{-1}\right)$, number of capsules (142.85 capsule plant $\left.{ }^{-1}\right)$ and thousand seeds weight ( 0.95 gr) were observed by using $80 \mathrm{~kg} \mathrm{ha}^{-1} \mathrm{P}_{2} \mathrm{O}_{5}$.
\end{abstract}

\title{
Ketencik (Camelina sativa L. Crantz) Bitkisinin Verim ve Kalitesi Üzerine Farklı Ekim Zamanları ve Fosfor Uygulamalarının Etkileri
}

\section{Article Info}

Received: 11.02 .2019

Accepted: 21.05.2019

Online Published 28.06.2019

DOI: 10.29133/yyutbd.525311

\section{Anahtar kelimeler}

Camelina sativa L.,

Fosfor dozları,

Ekim zaman1,

Verim
Öz: Bu çalışma, Camelina sativa (L.) Crantz’ nın bazı verim ve kalite özellikleri üzerine ekim zamanı ve fosfor uygulamalarının etkilerini belirlemek amacıyla Van ekolojik koşullarında 2014-2015 yıllarında yürütülmüştür. Deneme, Bölünmüş Parseller Deneme Deseni’ ne göre faktöriyel düzende 3 tekrarlamalı olarak kurulmuştur. Deneme faktörleri, (A) ekim zamanları (7-10 Nisan, 22-25 Nisan ve 7-10 Mayıs) ve (B) fosfor dozları (0, 40 ve $\left.80 \mathrm{~kg} / \mathrm{ha} \mathrm{P}_{2} \mathrm{O}_{5}\right)$. Bu çalışmada, bitki boyu, ilk kapsül yüksekliği, dal sayısı, kapsül sayısı, kapsülde tohum sayısı, bin tohum ağırlığı, tohum verimi, yağ oranı ve yağ verimi gibi özellikler incelenmiştir. Sonuçlar, ekim zamanlarının kapsülde tohum sayısı ve yağ oranı $(\mathrm{P}<0.05)$ hariç diğer incelenen tüm parametreler üzerindeki etkisinin istatistiksel olarak önemli bulunduğunu göstermiştir. İlk kapsül yüksekliği (28.86 $\mathrm{cm})$ ve bin tohum ağırlığı $(0.94 \mathrm{~g})$ gibi özelliklerde en yüksek değerler 7-10 Nisan ekim zamanından elde edilirken, en yüksek dal sayısı (12.48 adet), kapsül sayısı 
(130.33 adet), tohum verimi (1128.6 kg/ha) ve yağ verimi $(328.0 \mathrm{~kg} / \mathrm{ha}) 22-25$ Nisan ve 7-10 Mayıs ekim zamanlarından elde edilmiştir. Diğer taraftan, ilk kapsül yüksekliği, dal sayısı, kapsül sayısı ve bin tane ağırlığı üzerinde fosfor uygulamalarının etkisi istatistiksel olarak önemli $(\mathrm{P}<0.05)$ bulunmuştur. En yüksek ilk kapsül yüksekliği $(28.56 \mathrm{~cm}) 40 \mathrm{~kg} / \mathrm{ha} \mathrm{P}_{2} \mathrm{O}_{5}$ dozundan elde edilirken, en yüksek dal sayısı (12.41 adet), kapsül sayısı (142.85 adet) ve bin tohum ağırlığı $(0.95 \mathrm{~g}) 80 \mathrm{~kg} / \mathrm{ha} \mathrm{P}_{2} \mathrm{O}_{5}$ dozunun kullanılmasıyla elde edilmiştir.

\section{Introduction}

Camelina (Camelina sativa L.) which is an oilseed crop belongs to Brassicaceae family that its geographic origin is not precisely known, though distributed in three areas: surrounding region of Mediterranean Sea, Northern Europe and East Asia (Roman et al., 2012). It has long history of cultivation in different parts of the world and has been considered as an alternative biofuel (Frohlich and Rice, 2005) and oilseed crop and also as food supply with so many industrial uses (Gesch and Cermak, 2011). There are several species widely known for Camelina genus including C. sativa, $C$. rumelica, C. laxa, C. microcarpa, C. anomala and C. hispid which C. sativa is the only species with economic importance. Although the cultivated areas of camelina in not so widespread in Turkey (Katar et. al., 2012a; Kurt and Seyis, 2008), it has great potential of adaptation in different soil and climatic conditions (Zubr, 2003) such as semiarid and saline soils with low fertilization inputs (Moser and Vaughn, 2010) as well as dry areas (Sintim et al., 2016). Camelina oil contains different components such as tocopherol (700 mg/kg) (Katar et al., 2012a; Kurt and Seyis, 2008), polyunsaturated fatty acids (50-60\%) including oleic (C18:1), linoleic (C18:2), linolenic (C18:3) and eicosenoic (C20:1) acids (Gesch and Cermak, 2011), omega 3 (35-40\%) and omega 6 (15-20\%) (Gesch and Cermak, 2012; Zanetti et al., 2017). Yield and yield parameters are significantly influenced by factors such as sowing time as well as fertilization treatments especially phosphorus. Delay in sowing time significantly reduces seed and oil yield (Koncius and Karcauskiene, 2010), plant height (Katar et al., 2012a) and oil content (to 36.0 from $43.0 \%$ ) (Gesch, 2014). Phosphorus has also significant effects on plant growth increasing as well as root, seeds, flowers and fruit growing (Reigosa et al., 2004). Several parameters of camelina such as seed yield, number of branches, plant height and number of branches per plant were increased using phosphorus treatment (Arslan et al., 2014). This study was carried out in the aim of effects of different sowing time and phosphorus treatments on yield and yield parameters as well as oil content of camelina in Van region in Turkey.

\section{Materials and Methods}

\subsection{Cultural Practices and Crop Management}

The study was conducted during the years 2014-2015 in experimental fields, Department of Field Crops, Faculty of Agriculture, Van Yuzuncu Yil University (Van/Turkey). Average rainfall was $377.4-516.9 \mathrm{~mm}$ with a mean temperature of $11.20-9.45^{\circ} \mathrm{C}$ and $53.5-56.5 \%$ average humidity. The camelina seeds were provided by Department of Field Crops, Faculty of Agriculture, Selcuk University. Several soil parameters were measured before experiment as follows: soil texture determined as clay loam with high clay $(17.9 \%)$ and low salt $(0.021 \%)$, light alkaline $(\mathrm{pH}=8.4)$, low concentration of organic materials (1.85\%) and $\mathrm{N}(0.092 \%)$, P content was low (6.70 ppm) and useful $\mathrm{K}$ content was adequate $(488 \mathrm{ppm})$. The factorial experiment was designed based on split plot with two factors including (A) sowing times (7-10 April, 22-25 April and 7-10 May, with 15 days interval in each year) and (B) phosphorus fertilization $\left(0,40\right.$ and $\left.80 \mathrm{~kg} \cdot \mathrm{ha}^{-1} \mathrm{P}_{2} \mathrm{O}_{5}\right)$ in three replicates. Seeds were sown $\left(7.5 \mathrm{~kg} \mathrm{ha}^{-1}\right)$ by hand. Each plot size was $4 \times 1.25 \mathrm{~m}=5.0 \mathrm{~m}^{2}$ in 5 rows with row spacing of $25 \mathrm{~cm}$. All the plots were equally treated with $80 \mathrm{~kg} \mathrm{ha}^{-1}$ nitrogen fertilization (21\% ammonium sulfate). Harvested plants area was $2.25 \mathrm{~m}^{2}$. At the ripening, 10 plants were collected from each plot and several yield and quality parameters such as plant height $(\mathrm{cm})$, first capsule height $(\mathrm{cm})$, number of branches (branch plant ${ }^{-1}$ ), number of capsules (capsule plant ${ }^{-1}$ ), number of seeds in each capsule (seed capsule $\mathrm{e}^{-1}$ ), thousand seed weight (gr), seed yield $\left(\mathrm{kg} \mathrm{ha}^{-1}\right)$, oil content (\%) as well as yield (kg ha$\left.{ }^{1}\right)$ were measured. The harvesting time was between 25-29 July for the first sowing time, 05-08 August 
for second sowing time and 15-20 August for the last sowing time in each year. The seed yields obtained from the plots were recorded as yield per 1 ha with an average humidity of $15 \%$. The crude oil content was obtained using hexane as solvent on Soxalet type extractors and the results were determined as \% based on dry matter (Baydar and Erbaş, 2014).

\subsection{Statistical Analysis}

Data were subjected to analysis of variance (ANOVA) using COSTAT statistica (version 6.3) program. The means compared with Duncan Multiple Range Test (DMRT) at $\alpha=0.05$. Also, correlation analysis was done using IBM SPSS statistics (version 22.0) program (IBM Corp., 2013).

\section{Results}

Results showed that different sowing times had significant effect on plant height, first capsule height, number of branches, number of capsule, thousand seeds weight, seed yield and oil yield. Number of seeds in each capsule and oil content were not statistically affected by various sowing times and cultivation years. On the other hand, phosphorus treatments had significant effects $(\mathrm{P}<0.05)$ on first capsule height, number of branches, number of capsule and thousand seeds weight. The sowing times $\times$ phosphorus interaction was also found significant for some parameters such as number of capsules, thousand seeds weight as well as oil yield. Phosphorus treatments had significant no effects on plant height (Table 1). Plant heights were found 53.57- $56.81 \mathrm{~cm}$ by using different phosphorus treatments. In this study, number of seeds in the capsule was 14.07-15.25 in different sowing times and it was found 12.16-14.99 by using different phosphorus treatments. The effects of phosphorus treatments as well as sowing times $\times$ phosphorus interaction were not statistically significant on seed yield while differences between sowing times and the years were significant (Table 1). Seed yield was determined between 977.6 and $1021.2 \mathrm{~kg} \mathrm{ha}^{-1}$ based on phosphorus application. In our study, oil content was not affected significantly in all sowing times, phosphorus treatments and cultivation years. Oil content was detected between 27.20-27.89 \% at various sowing times. The effects of sowing times as well as sowing times $\times$ phosphorus interaction were statistically significant on oil yield while differences between phosphorus treatments and the years were not significant. On the other hand, oil yield was determined between $271.7-290.3 \mathrm{~kg} \mathrm{ha}^{-1}$ by using phosphorus doses.

\section{Discussion and Conclusion}

The highest plant height $(58.90 \mathrm{~cm})$ was obtained on 7-10 April but not statistically different from 7-10 May data. The least plant height $(51.72 \mathrm{~cm})$ was also observed on 22-25 April. The most first capsule height $(28.86 \mathrm{~cm})$ was also obtained on 7-10 April while the least one $(24.40 \mathrm{~cm})$ observed on 22-25 April but at the same statistical group with 7-10 May. Plant heights were found 53.57- $56.81 \mathrm{~cm}$ by using different phosphorus treatments. Katar et al., (2012a) showed that delay of sowing time decreases the plant height (from $43.10 \mathrm{~cm}$ to $85.47 \mathrm{~cm}$ ). Koc (2014) showed that plant height was 40.18-46.78 cm in different sowing times. Koncius and Karcauskiene (2010) reported that the best yield components parameters of camelina were obtained on sowing at 28 April but number of branches per plant, plant height and thousand seeds weight did not show any significant changes in this time. Phosphorus treatments had significant effects on first capsule height. The maximum first capsule height $(28.56 \mathrm{~cm})$ was determined by using $40 \mathrm{~kg} \mathrm{ha}^{-1}$ of phosphorus while the lowest first capsule height $(24.22 \mathrm{~cm})$ was determined by using $80 \mathrm{~kg} \mathrm{ha}^{-1}$ of phosphorus as the same statistical group with control. Arslan et al., (2014) has indicated that highest plant height $(124.5 \mathrm{~cm})$ obtained by using $90 \mathrm{~kg} \mathrm{ha}^{-1}$ phosphorus. Ylldırım, (2015) also showed that the most plant height $(92.24 \mathrm{~cm})$ and the most first capsule height $(77.65 \mathrm{~cm})$ were obtained by using $125.0 \mathrm{~kg} \mathrm{ha}^{-1}$ phosphorus while the lowest values (89.99 and $75.33 \mathrm{~cm}$, respectively) were observed by using $100.0 \mathrm{~kg} \mathrm{ha}^{-1}$. Research findings are determined more low from Coban and Onder (2014) who found the first capsule height 50.67-83.67 cm. Bolat, (2014) recorded that phosphorus treatment increased plant height from $61.7 \mathrm{~cm}$ to $64.7 \mathrm{~cm}$. 
YYÜ TAR BIL DERG (YYU J AGR SCI) 29 (2): 274-281

Tunçürrk/ Effects of Different Sowing Times and Phosphorus Application on Yield and Quality of Camelina (Camelina sativa L. Crantz)

Table 1. The effects of different sowing times and phosphorus treatments on some yield and yield components of Camelina

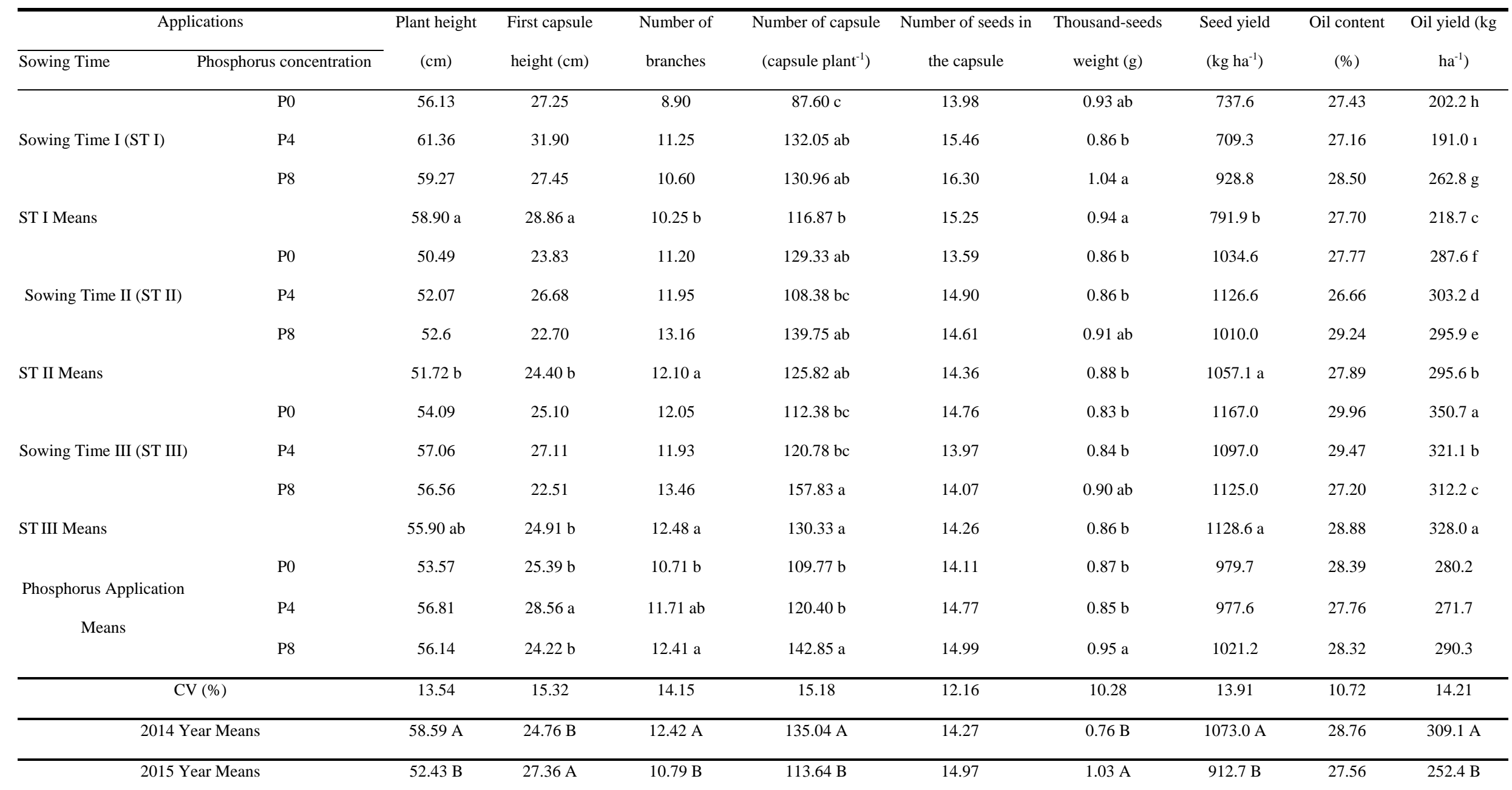

*, ** significant at the 0.05 and 0.01 level, respectively., Values within columns followed by the same letter are not significantly. Also, A and B letters were used for declared to the statistical differences between experimental years. 
The effect of sowing times, cultivation year and phosphorus treatments were significant on the number of branches (Table 1). The most number of branches (12.48) was obtained at 7-10 May while the least number of branches (10.25) was observed at 7-10 April. The second and last sowing times were at the same groups. On the other hand, the highest number of branches (12.41) was determined by using $80 \mathrm{~kg} \mathrm{ha}^{-1} \mathrm{P}_{2} \mathrm{O}_{5}$ while the lowest amount (10.71) recorded in control plots. 40 and $80 \mathrm{~kg} \mathrm{ha}^{-1}$ $\mathrm{P}_{2} \mathrm{O}_{5}$ applications were at the same groups. Arslan et al. (2014) showed that the highest number of branches (8.9) obtained by using $60 \mathrm{~kg} \mathrm{ha}^{-1} \mathrm{P}$ fertilizer while the least number (6.4) recorded in control plots. It was reported that number of branches were 8.28- 12.43 at different sowing times (Katar et al., 2012b) which is compatible with the results of present study. Also, Bolat (2014) showed that number of branches was 14.2 by using $30 \mathrm{~kg} \mathrm{ha}^{-1}$ phosphorus. The number of branches was obtained as 12.42 and 10.79 in the first and second experimental year, respectively. Differences between years, sowing times and fertilizer concentrations were found statistically significant $(\mathrm{P}<0.05)$ on agronomic traits such as number of seeds in the capsule and oil content. Number of seeds in the capsule changed between 13.59 to 16.30 and oil contents from 26.66 to $29.96 \%$. Koc (2014) showed that oil content was changed between 22.72 and $27.40 \%$ in different sowing times.

The highest number of capsules (130.33) was obtained on 7-10 May but not statistically different from 22-25 April data. The least number of capsules (116.87) was also observed on 7-10 April. Phosphorus treatments had significant effects on number of capsules. The maximum number of capsules (142.85) was determined by using $80 \mathrm{~kg} \mathrm{ha}^{-1}$ of phosphorus while the lowest number of capsules (109.77) was determined from control as the same statistical group with using $80 \mathrm{~kg} \mathrm{ha}^{-1}$ of phosphorus. The most number of capsules (157.83) was determined at 7-10 May with using $80 \mathrm{~kg} \mathrm{ha}^{-1}$ of phosphorus concentration. The least number of capsules (87.60) was observed at 7-10 April in control plots of phosphorus treatments. The highest thousand seeds weight $(0.94 \mathrm{~g})$ was recorded at 7 10 April and the lowest value (0.86 g) was obtained at last sowing time and in the same Duncan group with second sowing times. The maximum thousand seeds weight $(0.95 \mathrm{~g})$ was obtained using $80 \mathrm{~kg} \mathrm{ha}$ ${ }^{1}$ of phosphorus while the least thousand seeds weight (0.85) was determined using $40 \mathrm{~kg} \mathrm{ha}^{-1}$ of phosphorus as the same statistical group with control. Results showed that the most thousand seeds weight (1.04 g) was recorded at 7-10 April using $80 \mathrm{~kg} \mathrm{ha}^{-1}$ phosphorus. It was observed before that effects of phosphorus doses on thousand seeds weight (1.28-1.31 g) in camelina were significant which are in contrast with our results (Arslan et al., 2014). Also, in another study, it was showed that different sowing times had significant effects on thousand seeds weight (0.22-0.62 g) (Katar et al., 2012a). Katar et al. (2012b) indicated that thousand seeds weight varied between 1.19-1.28 gr at winter sowing time. In another study, the number of capsules and thousand seeds weight were 40.1594.75 capsule plant ${ }^{-1}, 0.79-0.89$ gr, respectively at different sowing times (Koc, 2014). Bolat (2014), recorded that phosphorus fertilizer positively affected thousand seeds weight. Czarnic et al. (2017), showed that seeds number inside each capsule, number of capsules and thousand seeds weight were 7.70- 9.50, 61.8- 116.8 and 0.87- 1.13 gr, respectively. Kiraly and Imbrea (2014) also indicated that the number of branches, number of capsules per plant and thousand seed weights ranged 13.74- 15.43; 138.42-164.26 and 1.19-1.32 gr, respectively based on sowing times.

The maximum value for the seed yield (1128.6 kg ha-1) was obtained at 7-10 May but at the same group with 22-25 April sowing time. Also, the minimum seed yield value (791.90 kg ha-1) was found at 7-10 April. Seed yield was determined between 977.6 and $1021.2 \mathrm{~kg} \mathrm{ha}^{-1}$ based on phosphorus application. The seed yield was detected as 1073.0 and $912.70 \mathrm{~kg} \mathrm{ha}^{-1}$ in the first and second year, respectively. Pavlista et al. (2011) reported that sowing times had significant effects on seed yield of camelina but not on oil content. Urbaniak et al. (2008) found no significant effects of sowing time on seed yield and oil content. Katar et al. (2012a) indicated that delaying of sowing times decreased seed yield. The most seed yield value (1206.0 kg ha) was recorded at 15 March and the least value (48.23 $\mathrm{kg} \mathrm{ha}^{-1}$ ) observed at $1^{\text {st }}$ May). Gugel and Falk (2006) reported that cool and dry conditions may increase seed and oil yields of camelina. Also, in other study, the highest seed yield value (2560 $0 \mathrm{~kg} \mathrm{ha}^{-1}$ ) was determined by using $200 \mathrm{~kg} \mathrm{ha}^{-1}$ phosphorous (Karahoca and Kırıcı, 2005). Yildırım (2015) showed that increasing phosphorus doses can effect positively on number of capsules per plant and number of seeds per capsule but decreased thousand seeds weight. In the same study, the highest seed yield (1979.0 kg ha-1) and oil yield (579.3 kg ha-1) values were obtained by using $75.0 \mathrm{~kg}$ $\mathrm{ha}^{-1}$ phosphorus while the highest oil ratio (29.33 \%) was observed by $100.0 \mathrm{~kg} \mathrm{ha}^{-1}$ phosphorus. Bolat (2014), recorded that phosphorus fertilizer positively affected seed yield and oil yield. Phosphorus 
application increased seed yield from $793.0 \mathrm{~kg} \mathrm{ha}^{-1}$ (control) to $973.0 \mathrm{~kg} \mathrm{ha}^{-1}$ (by using $60 \mathrm{~kg} \mathrm{ha}^{-1}$ $\mathrm{P}_{2} \mathrm{O}_{5}$ ) and oil yield from $279.0 \mathrm{~kg} \mathrm{ha}^{-1}$ (control) to $335.0 \mathrm{~kg} \mathrm{ha}^{-1}$ (by using $60 \mathrm{~kg} \mathrm{ha}^{-1} \mathrm{P}_{2} \mathrm{O}_{5}$ ). Gesch (2014) showed that the best times for spring sowing of camelina are mid-April and May. Koncius and Karcauskiene (2010) reported that the highest seed yield $\left(740.0 \mathrm{~kg} \mathrm{ha}^{-1}\right)$ was obtained at 8 April which was $39.0 \%$ and $33.0 \%$ higher than values observed at 13 April and 18 April, respectively. In another study, Sintim et al. (2016) showed that seed yield of camelina are 720.0-1068.0 kg ha ${ }^{-1}$. Czarnic et al. (2017) also recorded that seed yield was $1670-1870 \mathrm{~kg} \mathrm{ha}^{-1}$.

In our study, oil content was detected between 27.20-27.89 \% at various sowing times. Also, oil contents was obtained between 27-76-28.39 \% by different phosphorus doses. Katar et al. (2012b) observed that oil content was affected by different sowing times and it was ranged between 29.32 to 33.99 \%. Also, Arslan et al. (2014) showed that oil content varied between 25.31 to $29.65 \%$ based on phosphorus treatments. Y1ldırım, (2015) also reported that the highest oil ratio (29.33\%) was obtained by using $100.0 \mathrm{~kg} \mathrm{ha}^{-1}$ phosphorus application and the highest oil yield (579.3 kg ha-1) was recorded using $75 \mathrm{~kg} \mathrm{ha}^{-1}$ phosphorus treatment. Gesch, (2014) showed that oil content ranged from 36.0 to 43.0 $\%$ based on sowing times and decreased with delayed sowing. The highest oil yield (328.0 kg ha-1) was obtained at 7-10 May while the least oil yield (218.7 $\left.\mathrm{kg} \mathrm{ha}^{-1}\right)$ was observed at 7-10 April. On the other hand, oil yield was determined between 271.7-290.3 $\mathrm{kg} \mathrm{ha}^{-1}$ by using phosphorus doses. The highest oil yield value (350.7 $\mathrm{kg} \mathrm{ha}^{-1}$ ) was recorded at 7-10 May in control plots of phosphorus treatments, while the least value (191.0 kg ha-1) observed at 7-10 April by using $40 \mathrm{~kg} \mathrm{ha}^{-1}$ of $\mathrm{P}_{2} \mathrm{O}_{5}$ (Table 1). Katar et al. (2012c) showed that the most oil content value (34.03\%) and oil yield (410.8 kg ha $^{-1}$ ) were obtained at 15 March sowing time, while the least values $\left(20.57 \%\right.$ and $3.16 \mathrm{~kg} \mathrm{ha}^{-1}$, respectively) were observed at $1^{\text {st }}$ May sowing time.

\subsection{Correlation Analysis}

The results of bilateral correlation among different parameters indicated in Table 2. Results showed no significant correlation between plant heights with other parameters. There was negative significant correlation $(\mathrm{P}<0.01)$ between first capsule height and several parameters such as number of branches, seed yield and oil yield. The correlation between fist capsule height and thousand seeds weight was positively significant $(\mathrm{P}<0.01)$.

Table 2. Binary relations between the investigated characters

\begin{tabular}{|c|c|c|c|c|c|c|c|c|c|}
\hline Parameters & $\mathrm{PH}$ & FCH & NB & $\mathrm{NC}$ & NSC & TSW & SY & OC & OY \\
\hline PH & 1 & 0,163 & 0,102 & $-0,084$ & $-0,167$ & 0,075 & 0,026 & $-0,161$ & $-0,117$ \\
\hline $\mathrm{FCH}$ & & 1 & $-0,320 * *$ & $-0,051$ & 0,113 & $0,348 * *$ & $-0,369 * *$ & $-0,094$ & $-0,370 * *$ \\
\hline NB & & & 1 & 0,139 & $-0,239 *$ & $-0,217$ & $0,469 * *$ & $-0,044$ & $0,384 * *$ \\
\hline NC & & & & 1 & 0,139 & $-0,177$ & $-0,155$ & $-0,272 *$ & $-0,256^{*}$ \\
\hline NSC & & & & & 1 & 0,144 & $-0,256^{*}$ & $-0,337 * *$ & $-0,391 * *$ \\
\hline TSW & & & & & & 1 & $-0,231 *$ & 0,161 & $-0,199$ \\
\hline SY & & & & & & & 1 & 0,200 & $0,884^{* *}$ \\
\hline OC & & & & & & & & 1 & $0,554 * *$ \\
\hline
\end{tabular}

** Correlation is significant at the 0.01 and * at the 0.05 level (1-tailed). PH (Plant height), FCH (First capsule height), NB (Number of branches), NC (Number of capsule), NSC (Number of seeds in the capsule), TSW (Thousand-seed weight), SY (Seed yield), OC (Oil content), OY (Oil yield).

Number of branches had significant positive correlation $(\mathrm{P}<0.01)$ with seed yield and oil yield while had negative correlation $(\mathrm{P}<0.05)$ with number of seeds per capsule. Also, there was significant negative correlation among number of seeds per capsule and seed yield, oil content and oil yield. The correlation between thousand seeds weight and seed yield was negatively significant $(\mathrm{P}<0.05)$. On the 
other hand, the correlation between seed yield with oil yield and between oil content with oil yield were positively significant $(\mathrm{P}<0.01)$.

In the result of study, the highest positive values such as plant height $(58.90 \mathrm{~cm})$, first capsule height $(28.86 \mathrm{~cm})$ and thousand seed weight $(0.94 \mathrm{gr})$ were recorded at first sowing time (7-10 April), while second and last sowing times (22-25 April and 7-10 May) had most effects on seed yield amounts (1057.1 and $1128.6 \mathrm{~kg} \mathrm{ha}^{-1}$, respectively). Also, the best oil yield (328.0 $\mathrm{kg} \mathrm{ha}^{-1}$ ) was obtained at 7-10 May. Phosphorus treatments increased the first capsule height, the number of capsules, the number of branches and the thousand seeds weight values compared with control plots.

\section{References}

Arslan Y., Subası, I., Katar, D., Kodas, R., \& Keyvanoglu, H. (2014). Effect of different levels of nitrogen and phosphorus on the yield and yield component of false flax (Camelina sativa L.) Crantsz. Anadolu Journal Agr. Sci, 29 (3), 231-239.

Baydar, H., \& Erbaş, S. (2014). Oil Crops Science and Technology. SDU Publications, Pub number: 97, Isparta.

Bolat, C. (2014). The effects of different nitrogen and phosphorus doses yield and yield components of false flax (Camelina sativa). Master of Science Thesis, Department of Field Crops. Eskisehir Osmangazi Univ. Institute of Science, Eskisehir-Turkey.

Coban, F., \& Onder, M. (2014). The effects of sowing frequencies on the important agronomic properties of the Camelina sativa (L.) Crantz plant. Selcuk Journal of Agricultural Sciences, 1 (2), 50-55.

Czarnic, M., Jarecki, W., \& Jamro, D. B. (2017). The effects of varied plant density and nitrogen fertilization on quantity and quality yield of Camelina sativa L. Emirates Journal of Food and Agriculture., 29 (12), 988-993.

Frohlich, A., \& Rice, B. (2005). Evaluation of Camelina sativa oil as a feedstock for biodiesel production. Ind. Crops Prod., 21, 25-31.

Gesch, R. W., \& Cermak, S. C. (2011). Sowing date and tillage effects on fall-seeded camelina in the northern corn belt. Agronomy Journal, 103 (4), 980-987.

Gesch, R .W. (2014). Influence of genotype and sowing date on camelina growth and yield in the north central U.S. Industrial Crops and Products, 54, 209-215.

Gugel, R. K., \& Falk, K. C. (2006). Agronomic and seed quality evaluation of Camelina sativa in western Canada. Can. J. Plant Sci. 86, 1047-1058.

IBM Corp. (2013). IBM SPSS Statistics for Windows, Version 22.0. IBM Corp., Armonk, NY.

Karahoca, A., \& Kirıc1, S. (2005). Effect of nitrogen and phosphate fertilizer on seed yield and oil content of false flax (Camelina sativa L.) in Cukurova conditions. Cukurova University, Journal of Agricultural Faculty, 20 (2), 47-56.

Katar, D., Arslan, Y., \& Subas1, I. (2012a). Effects of different Sowing dates on yield and yield components of false flax (Camelina sativa (L.) Crantz under Ankara condition. Journal of Agricultural Faculty of Ataturk Univ., 43 (1), 23-27.

Katar, D., Arslan, Y., \& Subas1, I. (2012b). The effect of different sowing dates in fall on yield and yield components of false flax (Camelina sativa (L.) Crantz). Journal of Gazi Osmanpasa Universty, 29 (1), 105-112.

Katar, D., Arslan, Y., \& Subas1, I. (2012c). Determination of effect of different sowing dates on oil content and fatty acid composition in camelina (Camelina sativa (L.) Crantz) under Ankara ecological condition. Journal of Tekirdag Agricultural Faculty, 9 (3), 84-90.

Kiraly, M., \& Imbrea, F. (2014). Results concerning the influence of sowing period on crops in autumn-seeded Camelina sativa L. Research Journal of Agricultural Science, 46 (4), 88-93.

Koc, N. (2014). Determination of yield and some agronomic properties of added camelina (Camelina sativa L. (Crantz)) at different times. Master Thesis, Selcuk University. Konya,Turkey.

Koncius, D., Karcauskiene, D. (2010). The effect of nitrogen fertilizers, sowing time and seed rate on the productivity of Camelina sativa. Agriculture, 97 (4), 37-47.

Kurt, O., Seyis, F. (2008). Alternative oil plant: Camelina (Camelina sativa (L.) Crantz). OMU. Journal of Agricultural Faculty, 23 (2), 116-120. 
Martinelli, T., \& Galasso, I. (2011). Phenological growth stages of Camelina sativa according to the extended BBCH scale. Ann. Appl. Biol., 158, 87-94.

Moser, B.R., \& Vaughn, S. F. (2010). Evaluation of alkyl esters from Camelina sativa oil as biodiesel and as blend components in ultra-low sulfur diesel fuel. Bioresour. Technol., 101, 646-653.

Pavlista, A. D., Isbell, T.A., Baltensperger, D. D., \& Hergert, G. W. (2011). Planting date and development of spring-seeded irrigated canola, brown mustard and camelina. Ind. Crop Prod., 33, 451-456.

Reigosa, J. M., Pedrol, N., \& Sanchez, A. (2004). La Ecofisiologia Vegetal. Thompson, Madrid, Espana.

Roman, C., Vasquez, K., Martinez, G., Lillo, G., Fuster, R., Fuente, A., Uribe, J. M., Faundez, L. O., \& Paneque, M. (2012). Cultivos Energeticos una Apuesta de Futuro; Universidad de Chile: Santiago, Chile (In Spanish).

Sintim, H.Y., Zheljazkov, V. D., Obour, A. K., Garcia, A. G., \& Foulke, T. K. (2016). Evaluating agronomic responses of camelina to seeding date under rain-fed conditions. Agronomy Journal, 108 (1), 349-357.

Urbaniak, S. D., Caldwell, C. D., Zheljazkov, V. D., Lada, R., \& Luan, L. (2008). The effects of seeding rate, date and seeder type on performance of Camelina sativa L. in the Maritime provinces of Canada. Can. J. Plant Sci., 88, 501-508.

Yildırım, H. (2015). Effects of nitrogen and phosphorus doses on some of the yield and quality components in camelina (Camelina sativa (L.) Crantz). The Graduate School of Natural and Applied Science of Selçuk University The Degree of Master of Science in Field Crops. Konya, Turkey.

Zanetti, F., Eynck, C., Christou, M., Krzyzaniak, M., Righini, D., Alexopoulou, E., Stolarski, M. J., Van, E. N., Puttick, D., \& Montia, A. (2017). Agronomic performance and seed quality attributes of Camelina (Camelina sativa L. crantz) in multi-environment trials across Europe and Canada. Industrial Crops \& Products, 107, 602-608.

Zubr, J. (2003). Qualitative variation of Camelina sativa seed from different locations. Ind. Crops Prod., 17, 161-169. 